\title{
Redactioneel
}

\section{Burgerperspectieven in toezicht}

\author{
Anna Merz en Frans van Bruggen*
}

De afgelopen jaren zijn er veel voorbeelden in het nieuws geweest van zaken waarin burgers de dupe zijn van een falende overheid. De toeslagenaffaire is hiervan waarschijnlijk het duidelijkste voorbeeld: jarenlang werden burgers onterecht als fraudeurs bestempeld. De oorzaak: de overheid had geen oog (meer) voor het publieke belang en was doorgeslagen in het streng handhaven van regels. Ook bij de gaswinning in Groningen werd de burger te lang genegeerd en het publieke belang jarenlang te licht opgevat, met instortende huizen, psychische problemen bij Groningers ${ }^{1}$ en afbrokkelend vertrouwen als gevolg. ${ }^{2}$ Gezien het falen van de overheid zijn er inmiddels in beide casussen parlementaire enquêtecommissies ingesteld 'om inzicht te krijgen in de besluitvorming en om te komen tot waarheidsvinding' ${ }^{3}$ Wat kan het toezicht hiervan leren?

Er lijken zich in bovengenoemde casuïstiek drie problemen voorgedaan te hebben die het toezicht raken. Allereerst de (ernst van) afwezigheid van toezicht. In de casus van de toeslagenaffaire bleek er geen toezicht te zijn. Mede hierdoor is er momenteel een inspectie in oprichting die moet toezien op de werkzaamheden van de Belastingdienst, inclusief de handhaving op mogelijke fraude. ${ }^{4}$ In het Groningendossier was Staatstoezicht op de Mijnen (SodM) de aangewezen toezichthouder.

* A. Merz MA is promovenda bij de sectie Criminologie van de Erasmus Universiteit Rotterdam en redactielid van Tijdschrift voor Toezicht. Drs. F.P. van Bruggen is buitenpromovendus en toezichthouder bij De Nederlandsche Bank en redactielid van Tijdschrift voor Toezicht.

1 'Onderzoekers: Groninger aardbevingen kunnen leiden tot doden', Trouw 31 januari 2018.

2 Rijksuniversiteit Groningen, 'Gaswinning: wat vinden inwoners van de provincie Groningen?', beschikbaar via www.rug.nl/research/ earthquakes/groningers.

3 'Parlementaire enquête naar aardgaswinning Groningen van start', Tweede Kamer, Kamernieuws 11 februari 2021.

4 'Oprichting Inspectie Belastingdienst, Toeslagen en Douane', Rijksoverheid nieuwsbericht 6 november 2020.
Deze bleek echter pas in 2012 'wakker' te worden en in te grijpen. De voorbeelden laten zien dat nut en noodzaak van toezicht vaak pas echt duidelijk werden als het er niet is.

Een tweede punt dat het toezicht raakt, is een te legalistische instelling door de overheid. Juridische normen kregen duidelijk de voorkeur boven maatschappelijke, sociale en morele waarden, met zwart-witdenken als gevolg. Fraude, inclusief 'foutjes', werd als fout bestempeld en moest worden afgestraft. Daarnaast waren er contracten en afspraken die nagekomen werden. Als deze regels gevolgd worden, is er niets aan de hand toch? De voorbeelden laten de gevolgen van deze legalistische instelling zien. Wet- en regelgeving werden gebruikt om zich erachter te verschuilen en persoonlijke verantwoordelijkheid werd niet genomen (zelfs niet door rechters in het geval van de toeslagenaffaire). Juist hier had het toezicht een belangrijke rol kunnen spelen. In het borgen van de publieke belangen is de 'juridische ruggengraat' voor de toezichthouder weliswaar van doorslaggevend belang, maar wetgeving kan natuurlijk nooit op zichzelf staan. Er moet een duidelijk publiek doel onder liggen. De toezichthouder legt wet- en regelgeving daarom altijd uit in de maatschappelijke context waarin hij opereert. Het dienen van publieke belangen gaat verder dan het blind volgen van regels. De 'risico's' van een te legalistische instelling is binnen het toezicht immer reeds lang bekend. Vandaar ook de draai naar het gebruik van gedragsinzichten om versterkt in te zetten op preventief toezicht, oorzaken belichten in plaats van alleen symptomen bestrijden en te kijken hoe ondertoezichtstaanden eventueel (vrijwillig) bereid zijn hun gedrag aan te passen. Een toezichthouder had bij uitstek dit perspectief kunnen inbrengen in de genoemde affaires (zeker omdat zelfs de rechter dit niet deed). Toezicht had hier met zijn ervaringen een doorslaggevende rol kunnen spelen: door te staan voor de maatschappelijke waarden die ten grondslag liggen aan de instrumenten 
(wet- en regelgeving) die nodig zijn om de publieke doelen te realiseren.

Het derde probleem bij deze affaires dat het toezicht raakt, ligt in het verlengde van het tweede: het burgerperspectief werd genegeerd door de overheid. In de 'bredere' discussie binnen het toezicht is hier in het verleden ook aandacht voor geweest. In een interview in dit tijdschrift met Alex Brenninkmeijer in 2013 (TvT 2013, afl. 4) bekritiseerde de auteur toen al dat toezicht burgers niet meer aanspreekt. De Zwart en Van Muijden pleitten in 2021 (TvT 2021, afl. 2) voor een systeem dat meer 'uitgaat van de positie van de kwetsbare burger'. Het ontbreken van sterk en onafhankelijk toezicht - losgekoppeld van de uitvoerende macht van Brenninkmeijer in 2013 - is juist wat Kockelkoren, inspecteur-generaal bij SodM, in een recent verschenen interview in NRC Handelsblad ${ }^{5}$ aan de kaak stelt en waar het in de toeslagenaffaire en de gaswinning in Groningen mis is gegaan. In Toezine sprak Kockelkoren begin dit jaar over een behoefte aan 'next level toezichthouders', ${ }^{6}$ gekenmerkt door zichtbaarheid, vooral naar burgers toe. Binnen het toezicht is dit burgerperspectief dus op zich niet nieuw; in de praktijk werd er echter toch te weinig mee gedaan.

Vandaar dat uit verschillende hoeken steeds meer vragen en initiatieven ontstaan naar meer betrekking van burgers in handhavingspraktijken om het publieke belang beter te borgen. De Inspectie Gezondheidszorg en Jeugd organiseerde samen met het Nederlands Instituut voor Onderzoek van de Gezondheidszorg in 2017 een Burgerplatform ${ }^{7}$ als verkenning van mogelijkheden om burgers te betrekken bij toezicht. Ook het visietraject 'Naar nieuwe vormen van integraal toezicht' van een aantal gemeentes en rijksinspecties van Toezicht Sociaal Domein past in deze trend. In een minicollege ${ }^{8}$ over de betekenis van de coronacrisis voor de bestuurswetenschap afgelopen jaar spreekt Marc Hertogh, hoogleraar rechtssociologie aan de Rijksuniversiteit Groningen, zich uit voor meer burgerperspectief in handhaving. Hertogh pleit voor handhaving die afgestemd is op de achtergrond van individuele burgers (seeing like a citizen). En ook in de podcastserie van de Inspectieraad, De Toekomst van Toezicht, is in 2020 een aflevering over het 'Burgerperspectief in toezicht' verschenen. Burgers betrekken is hot (en noodzakelijk) - ook zoeken veel toezichthouders nog naar de juiste manier waarop ze in hun inspecties beter op de behoeftes en gevoelens van burgers kunnen inspelen.

Deze zoektocht laat echter ook een onderliggend probleem in de relatie tussen toezicht en burgers zien: het gebrek aan diversiteit in toezicht. In hoeverre is een toezichtland dat voornamelijk uit een 'wit bolwerk' bestaat überhaupt in staat om het heterogene perspectief van burgers mee te nemen? Als de werelden van toezicht en burger zodanig ver uit elkaar liggen blijft met moeilijk om de ander mee te nemen. Hier ligt een belangrijke maar ook moeilijke taak voor toezicht: ga het gesprek aan met burgers en investeer in relaties en vertrouwensbanden.

Een eerste stap hierin kan het herkennen van je eigen bias (denkfouten) zijn: het centrale thema in het peerreviewed artikel van Coffeng, Van Steenbergen, De Vries en Ellemers over de vraag in hoeverre toezichthouders oog hebben voor hun eigen denkfouten. Hun advies voor toezichthouders is om een voortdurend kritische blik op elkaars aannames te hebben om waakzaam te blijven. Een tweede, daarmee samenhangend, aspect wordt gevormd door onderliggende mensbeelden die immers onze besluitvorming kunnen beïnvloeden.

In de rubriek Boekbespreking reflecteren Frans van Bruggen en Frédérique Six op het overheersende mensbeeld in het toezicht (als dit überhaupt bestaat): zijn de ideeën uit Bregmans boek De meeste mensen deugen ook toepasbaar op het toezicht? Of is 'gezond' wantrouwen meer op zijn plaats?

In zijn column 'De kracht van tegenspraak' stelt eerder genoemde inspecteur-generaal bij SodM Theodor Kockelkoren de kwaliteit van openbaar bestuur op de proef. Kockelkoren benadrukt het belang van een reflectieve rol in het toezicht en roept toezichthouders op weg uit de zijlijn te stappen.

In het voorlopig laatste interview in onze serie 'De toezichtinterviewestafette' gingen we met Rosita Thé, directeur van de omgevingsdienst van DCMR Milieudienst Rijnmond, in gesprek over toekomstbestendigheid, de menselijke maat en dilemma's van VTH-diensten. De DCMR maakt gebruik van verschillende manieren om burgers te betrekken bij het toezicht; van kinderraad tot burgergesprekken en het delen van informatie over klachtafhandelingen.

In onze serie 'Interview met een pas gepromoveerde' spraken we met Noortje de Boer over openbaarmaking in toezicht. De Boer keek in haar promotieonderzoek naar de gevolgen van openbaarmaking van toezichtbevindingen op de relatie tussen inspecteurs (NVWA) en burgers en komt met deels verrassende resultaten: openbaarmaking hoeft niet per se eng te zijn maar biedt juist ook kansen voor street-level bureaucrats.
'Toezichthouder pleit voor meer onafhankelijkheid van Haagse invloed', NRC 17 juni 2021.

6 '"Next level toezicht houden" is meer begrip voor het belang van burgers', Toezine 2 februari 2021.

7 Nivel, 'Wat verwachten en wensen burgers van de Inspectie Gezondheidszorg en Jeugd?' 2019.

8 Beschikbaar via www.youtube.com/watch?v=S_Kd5wNReZ8\&t=7s. 